\title{
Communicating climate change findings from IPCC reports: Lessons from outreach events in India
}

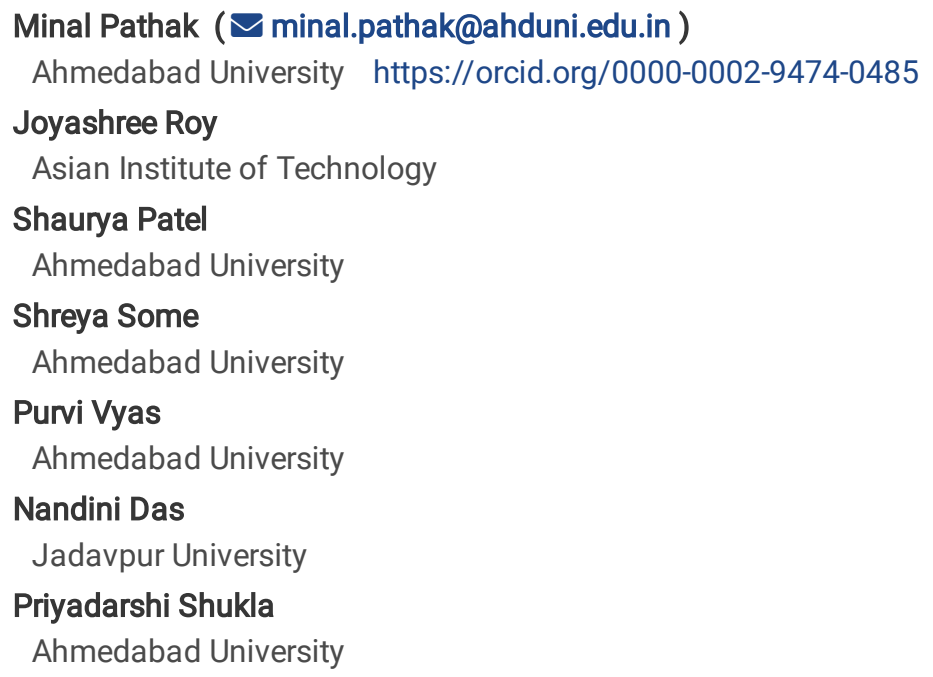

\section{Research Article}

Keywords: Strategic communication, Public Engagement, IPCC, Communication, Outreach, India

Posted Date: February 24th, 2021

DOI: https://doi.org/10.21203/rs.3.rs-163512/v1

License: (c) (i) This work is licensed under a Creative Commons Attribution 4.0 International License. Read Full License 


\section{Abstract}

India has been collaboratively hosting public dissemination events to communicate climate change science and knowledge using Intergovernmental Panel on Climate Change (IPCC) reports since 2007. All three special reports from Sixth Assessment cycle have been presented in multiple outreach events in various states of India. The primary aim has been to satisfy the growing appetite among various social groups for reliable scientific understanding of climate change and the solution space. The study includes insights from 18 physical outreach events conducted in India. The format ranged from very large public events with mixed stakeholder presence in the audience with presence of national/subnational policy makers; workshops, meetings and seminars with implementing sectors and investors, financial institutions, NGOs and a third category with knowledge generators, researchers, teachers and students. The follow up mass media and social media coverage have been a positive spin off. The events provided platform for open discussion on bottom-up local good practices, very localised impacts and connection to climate systems and reasons for concern and action. Feedback received is rich and rewarding. Face to face outreach events have enormous co benefits and trust building scope as side talks, coffee time talks, small side meetings, casual clarifications all help in providing space to participants for dispelling doubts, build long term research collaborations and they become ambassadors and adopters of IPCC science. Overall, the events were hugely successful, however many more such events, especially in local languages are needed to ensure messages of the IPCC reach the wider stakeholders.

\section{Introduction}

\subsection{Climate Change Communication: Indian context}

Researchers and scientists have long studied the process by which communication influences public knowledge, actions, attitudes and behaviour with regards to important societal issues. Research has focused on the potential of strategic (or purposive) communication to enhance public engagement, example health behaviour such as drunk driving, vaccination, smoking prevention, etc. using diverse media including radio, television, newspapers and digital media (Roser-Renouf and Maibach 2018). Majority of the cases focused on changing the behaviours of at-risk individuals, although some also focused on building public support for policy changes, such as banning of smoking from public spaces (Roser-Renouf and Maibach 2018). Communicating science of climate change fits well in strategic communication as reports of the Intergovernmental Panel on Climate Change (IPCC) seek to inform policymakers and the wider society on the responses to climate change including actions that different stakeholders can take and how these could influence greenhouse gas emissions and hence the physical climate. The messages from IPCC reports are therefore diverse and of different relevance for different social actors. News media plays a critical role for public awareness and perception of climate change (Moser 2010). Media coverage of climate change has been an important tool to set the policy agenda on climate change, and to influence public discourse, behaviour, and perception on climate change (Keller et al. 2020). This has led to creation of a study area focusing on media coverage of climate change and the environment.

Social context and public readiness are congenial for any new knowledge dissemination. Historically over past few decades in India, media and communication has been deployed as a means for creating public engagement on various large scale social change (Verma et al. 2017; Chadha 2017; Kapoor et al. 2018). India has very high newspaper reading habits. Nearly400 million people read newspapers (MRUC India 2019). For those who cannot read newspapers, the television acts as an important medium as $~ 840$ million have access to television (MRUC India 2019). India's Integrated Agro-meteorological Advisory Service (IAAS) program is one of the largest agrometeorological information programs in the world. It provides information to all farmers of 718 districts of via, radio, mobile, TV, newspapers, personal contacts, local farmer's knowledge networks and State Agriculture Department. This represents a historically time tested successful medium of communication in India for managing agricultural extension services and related advisories which help endogenizing weather and climate variability in decision making by farmers. These are used for climate proofing in agriculture (For more discussion on IAAS see Maini and Rathore 2011; Rathore et al. 2011).Communicating climate change has much to learn from these past practices. Analysing a national survey of 4031 Indian adults, Leiserowitz \& Thaker (2012) found people were personally observing changes in their local rainfall, temperatures and weather patterns and their perception towards climate change has evolved as their understanding improved through its increased focus in popular media. $73 \%$ of the respondents found scientists to be the most trusted source for information on climate change. According to the Global Trustworthiness Index survey conducted in 2019, 67\% of India's urban population considers "scientists" as the most trustworthy profession and the information shared by them is considered to be trustworthy and globally the number accounts for $60 \%$ of the population (IPSOS 2019). In India, this is linked to a deeper socio-cultural root of desire for higher learning where spending time and money on education is a priority decision for households. The average share of expenditure on higher education in urban households is $18.4 \%$ and $15.3 \%$ for rural households which have at least one member pursuing higher education (Chandrasekhar et al. 2019).

A study of the time allocated to environment and climate change during television primetime (7-11 pm), which is largely influenced by commercial interests, reflect a different story. In 2009 , only $1.5 \%$ of prime time television focused on the environment which further dropped

Page $2 / 20$ 
to $0.2 \%$ in 2014 (CMS 2014). There are very few daily debates on environmental or climate change on Indian television today. The ones that were occasionally conducted happened when i). when media companies received scientific support for special analysis (Nivas et al. 2016) ii) In a spotlight context or attention cycles for example media coverage of Delhi's air pollution issue, when these were politically driven (Murukutla et al. 2017) or iii) during a significant event (such as World Environment Day) (Boykoff and Luedecke 2016), Paris agreement or meetings of the Conference of the Parties (COP) (Boykoff 2010; Schäfer and Schlichting 2014; Schmidt and Schäfer 2015). While the coverage of climate change has declined on television, these have increased substantially in newspapers over the past two decades in India (Keller et al. 2020).

One positive example of this growing attention was the inclusion of 'climate change' in the official name of India's Environment Ministry. In 2014, following successful participation in several international negotiations, India's Ministry of Environment, Forests (MoEF) was renamed Ministry of Environment, Forests and Climate Change (MoEFCC). Currently information related to climate change at national level is controlled by the MoEFCC. MoEFCC is the nodal agency for submitting India's National Communications to United Nations Framework Convention on Climate Change (UNFCCC) (UNFCCC, 2021). MoEFCC relies on Press Information Bureau (PIB) of India to disseminate information to the print, electronic and online media, on subjects related government laws, policies, programme initiatives, welfare activities and achievements (Press Information Bureau 2005). However, the transparency of communications and access to information from the Government of India has been questioned. According to India's second Biennial Reports (BR) to the UNFCCC, India's emissions intensity had reduced by 21 per cent between 2005 and 2014. Subramanian, (2019) argued that, it is difficult to verify this information because the official emissions data is not made publicly available for 2005 , the crucial baseline year of reporting. A simple google search for following words "India Second Biennial Report to UNFCCC" on $18^{\text {th }}$ January 2021, displayed only 186 results which suggest that official communications related to climate change information is not viewed a high priority. According to Bhatta (2013), this is because of "shortage of science journalists, commercial pressures and a feeling that their coverage does not make a difference all play a role." Along the same lines, Shreeshan, (2018) described India's journalists "woefully underprepared to connect the dots of climate change" and considered the act of reporting on climate change for most corporate newsrooms a conflict of interest.

All these set the context for enormous thirst for credible knowledge on climate change and science of it among experts, public in general and academia and also journalists and specially science journalists in India. In this backdrop, the IPCC being the apex body of the United Nations for assessing science of climate change, has been rightly promoted through information dissemination in India, as a credible source of peer reviewed knowledge and evidence on climate change. So far, most of the studies related to climate change and communications in India has primarily considered mass media such as newspapers, TVs, print media etc as part of their studies (Billett 2010; Boykoff 2010; Nivas et al. 2016; Parveen 2016; Thaker 2017; Keller et al. 2020). To the best of our understanding, no study has so far focused on India's strategic communication on climate change with regards to IPCC reports. Therefore, this study is the first attempt to understand the lessons learnt from climate change communication through IPCC outreach events in India.

\subsection{Climate Change Communication and IPCC}

Communication on climate change in the mass media was often driven by stakeholders with vested interests resulting in incorrect or inadequate scientific understanding and consensus (Moser 2010). Today after more than 30 years of scientific progress and with high greater scientific consensus (Cook et al. 2013, 2016) public climate change communication is no longer a match between 'duelling experts $^{[8]}$. Media practices, media training have evolved and improved bringing in the public awareness and understanding of climate change more so at least in developed countries. The concern, sense of urgency and actions vary greatly across populations and understanding of the cause of climate change and its risk remains limited. The issues debated in public have moved beyond whether or not climate change is real and is caused by human activities, however a small modicum of doubt and scepticism lingers in various groups of societies. Public discourse on climate change has moved from the most basic impacts on physical and ecological systems towards a more interconnected and multidisciplinary understanding. Policy debates in public discourse over the years have evolved from Kyoto Protocol to Paris agreements, this has further raised the awareness of the issue in the general public (Sampei and Aoyagi-Usui 2009; Poberezhskaya and Ashe 2015; Svoboda 2020).

Several community-based organisations, research think tanks, private businesses, etc. associated with the field of climate change are now increasingly aware about the functioning of IPCC. In its early years, IPCC as an organization did not touch upon the public consciousness (Lynn 2018). This was dramatically changed with publication of the AR4 in 2007 (IPCC 2007) which attracted widespread attention around the world for its findings and as result of the work it led to IPCC winning Nobel Peace Prize in 2007 (Norwegian Nobel Committee 2007). It is important to note that IPCC did not produce its own press releases, but mainly relied on the sponsoring organisations (WMO \& UNEP) to carry out on its behalf. Presently IPCC reports are considered the gold standard in climate change assessments (Lynn 2018). The

Page $3 / 20$ 
recommendations of Inter Academy Council (IAC) accepted by IPCC (InterAcademy Council 2010), led to more clear communication strategy with a detailed implementation plan and since then "Senior Communications Manager" is recruited to manage communications profile (IPCC 2012).

IPCC's communication has evolved over the years addressing critical issues of communicating key findings in a more reader friendly way free from jargons whilst maintaining its scientific integrity. The key messages of Assessment Report (AR5) were delivered successfully in the press releases due to the engagement of the Working Group Co-chairs (especially for Synthesis Report, the IPCC Chair) and the technical advice for mass media communication provided by the communications teams. The AR5 communications strategy had two key features: 1) IPCC ensured to put reporters in touch with the authors of the relevant sections of the report, who could interview as experts in their own rights, while being connected with IPCC. Thus it led to IPCC positioning itself as a resource for reporters (Lynn 2018). 2) From a technical perspective as the value of communications and media grew within the IPCC, it started introducing embargoed releases of the reports (Lynn 2018). Which means that certain accredited or registered reporters had access to materials before the actual date of release. This was first trialled in the Special Report on Extreme Events (SREX) in 2012 of IPCC, and eventually rolled out for the whole of AR5 (Lynn 2018). This process was extremely effective in India in Sixth assessment cycle and helped creating the longer lasting communication materials. The summary video contains the key messages based on the report's findings. The videos contain messages from the authors and chairs of the working groups thereby giving a personal touch to the key messages (IPCC 2016a). The communication method involved chairs, authors, professional filmmakers and photographers who used compelling visuals to make key messages more digestible to people with varying backgrounds as well as making sure the messages are shared as intended. These enhanced communications materials with compelling visuals made for a reliable resource for speakers.

Based on the request of the UNFCCC and a call from several governments, in 2018 the IPCC prepared a special report on the impacts of global warming of $1.5^{\circ} \mathrm{C}$ above pre-industrial levels with cumulative efforts of 90 authors (from 44 countries) reviewing $6000+$ peerreviewed studies. One of the key findings of the report was that the climate risks posed to the natural and human systems are higher in case of $2^{\circ} \mathrm{C}$ warming than $1.5^{\circ} \mathrm{C}$ warming above pre-industrial levels and that the global warming was likely to reach $1.5^{\circ} \mathrm{C}$ between 2030 and 2042 at the 2017 rate of emissions (IPCC 2018). The report was hugely impactful (Lindwall 2018; Stockholm Resilience Centre 2018; Livingston and Rummukainen 2020). In October 2018, media coverage of the SR15 contributed to an increase in stories that mentioned climate change or global warming by $43 \%$ throughout the world from the previous month of September 2018 (Nacu-Schmidt et al. 2019). In December 2009 Copenhagen Climate Change Conference and the November of 2015 Paris Agreement negotiations, climate coverage increased by $40 \%$ and $43 \%$ respectively as compared to its previous month (Nacu-Schmidt et al. 2019). After both of these events, media coverage of climate dropped back down to the previous level within a month of two, whereas coverage of SR15 has continued to generally rise (Nacu-Schmidt et al. 2019; Boykoff and Pearman 2019). This impact is because of the public discussions about climate change via mass media. News media throughout the world have consistently used dire language for covering SR15 reports (Boykoff \& Pearman, 2019). However as Weber, (2010) discussed that moral (rather than analytical or emotional) influences on decision-making hold the most promise for sustainable behavioural change.

Amelung et al. (2016) explained that the key driver of IPCC report's low readability may be its iterative editing procedure, going back and forth between the governments and IPCC teams. The long process of evaluation and modification may adversely affect the readability of the document, because clear statements may be avoided in response to critical comments during the editorial process (Amelung et al. 2016; Howarth and Painter 2016). Also, the texts are extremely detailed because each statement has to be supported with reference to the underlying literature. As these details stands in sharp conflict with space constraints (e.g. a limit of 25 pages for all aspects related to health), text may then be condensed into highly complex graphs, which in turn affects comprehensibility (Amelung et al. 2016; Harold 2017; Broek 2020). IPCC has formulated its method of public engagement wherein the scientists associated with IPCC are trained and encouraged and supported to engage with media, universities, research organisations and think tanks in dissemination processes through workshops, conferences, special lectures for special groups example school students to ensure that the key messages of the reports of IPCC are conveyed without distortion to the masses. This is the method which India also adopted of strategic public engagement of the recent IPCC special reports.

\subsection{IPCC Sixth Assessment Report (AR6): outreach events in India}

In 2015, the Panel of the IPCC called for a meeting where experts, IPCC focal points and other IPCC representatives could share experiences, best practices and lessons learnt from the past communications and outreach activities of the AR5 to inform and help in developing the communication strategy for AR6 (IPCC 2016b). In AR6, each of the three Working Groups appointed a dedicated Head of Communications whose primary job is for developing and delivering the group's communications and engagement strategy and activities, supporting the Technical Support Unit (TSU) staff and IPCC authors besides just communicating science also to lead in co-organising and initiating 
outreach events. During the Special Report on the Global Warming of 1.5C, the Communications team worked for months preparing communications material. This included diverse outputs such as media briefs, short video, presentation slides, simplified key messages and designing the overall media strategy to bring harmony and standardisation in communicating messages. IPCC also hired a professional communications team to improve the visual communication of the products (IPCC 2016c, 2021; Info Design Lab 2019). All these became very useful products for outreach events in India. In the next section we present research methodology and design

Since 2007, after the publication of Fourth Assessment Report (AR4), India very systematically engaged on communicating the key messages from IPCC reports. This article does not make any detailed statement or evaluation of IPCCs overall communication strategy. We only refer to some of those for making a link to dissemination events that were organised over time in India. In the following sections we focus on a list events by typology in India, contents shared, mode of communication and participants' engagement followed by an analysis. The analysis focuses on the key elements of communication and whether the communication strategy helped for more effective communication. Table 1 summarises the observations from 18 events organised officially in collaboration with IPCC communication/Technical support unit between 2007 and 2019. Reliability of source in any information plays an extremely important role in getting public attention and engagement. Therefore, introducing IPCC to the audience consistently remained a constant feature of all dissemination events in India. At every event, participants were reminded of the high standards of transparency, review and assessment adhered to by the IPCC. We do claim to provide a chronological narrative but add some feedback/response analysis based on most recent ones.

\section{Table 1 List of outreach events in India}




\begin{tabular}{|c|c|c|c|c|c|c|c|}
\hline Sr.No. & Title & $\begin{array}{l}\text { Date \& } \\
\text { Location }\end{array}$ & Aims/objectives & $\begin{array}{l}\text { Type of event } \& \\
\text { number of sessions }\end{array}$ & Audience & $\begin{array}{l}\text { Full/Half } \\
\text { day }\end{array}$ & $\begin{array}{l}\text { Number of } \\
\text { participants }\end{array}$ \\
\hline 1 & $\begin{array}{l}\text { Roundtable on } \\
\text { Urban India and } \\
\text { Climate Change } \\
\text { Research }\end{array}$ & $\begin{array}{l}\text { December } \\
\text { 2018, New } \\
\text { Delhi }\end{array}$ & $\begin{array}{l}\text { Linked to SR15 } \\
\text { findings - } \\
\text { Presented on } \\
\text { 'Urban } \\
\text { transformations } \\
\text { for } 1.5^{\circ} \mathrm{C} \text { : A } \\
\text { revised } \\
\text { framework for } \\
\text { Indian cities/ }\end{array}$ & Roundtable & Researchers & Half day & 70 \\
\hline 2 & $\begin{array}{l}\text { Road to IPCC's } \\
\text { Sixth Assessment } \\
\text { Report }\end{array}$ & $\begin{array}{l}\text { January } \\
\text { 2019, New } \\
\text { Delhi }\end{array}$ & $\begin{array}{l}\text { Share findings } \\
\text { of the special } \\
\text { report SR1.5 } \\
\text { IPCC and AR6 } \\
\text { report - foster } \\
\text { engagement } \\
\text { across different } \\
\text { sectors and } \\
\text { stakeholders } \\
\text { acting on } \\
\text { climate change }\end{array}$ & $\begin{array}{l}\text { Conference, } 5 \\
\text { sessions }\end{array}$ & $\begin{array}{l}\text { Policymakers, } \\
\text { industry (steel, } \\
\text { cement, } \\
\text { automobile), } \\
\text { finance sector, } \\
\text { civil society } \\
\text { organisations }\end{array}$ & Full day & 150 \\
\hline 3 & $\begin{array}{l}\text { 'Systems } \\
\text { Transformations } \\
\text { for Global } \\
\text { Warming of } 1.5^{\circ} \mathrm{C}\end{array}$ & $\begin{array}{l}\text { January } \\
2019, \\
\text { Ahmedabad }\end{array}$ & $\begin{array}{l}\text { Share findings } \\
\text { of the special } \\
\text { report SR1.5 } \\
\text { and IPCC AR6 } \\
\text { report - foster } \\
\text { engagement } \\
\text { across different } \\
\text { sectors and } \\
\text { stakeholders } \\
\text { acting on } \\
\text { climate change }\end{array}$ & $\begin{array}{l}\text { Conference, } 4 \\
\text { sessions }\end{array}$ & $\begin{array}{l}\text { Policymakers, } \\
\text { researchers, } \\
\text { university } \\
\text { students, civil } \\
\text { society } \\
\text { organisations }\end{array}$ & Full day & 83 \\
\hline 4 & $\begin{array}{l}\text { One Planet: Re- } \\
\text { imagining our } \\
\text { future }\end{array}$ & $\begin{array}{l}\text { January } \\
2019, \\
\text { Ahmedabad }\end{array}$ & $\begin{array}{l}\text { Share findings } \\
\text { from IPCCs } \\
\text { Special Report } \\
\text { on Global } \\
\text { Warming of } 1.5 \\
{ }^{\circ} \mathrm{C}\end{array}$ & $\begin{array}{l}\text { Talk/Lecture, } 1 \\
\text { session }\end{array}$ & School students & Half day & 100 \\
\hline 5 & $\begin{array}{l}\text { Climate Change } \\
\text { and India: } \\
\text { Conversing } \\
\text { Across } \\
\text { Disciplines }\end{array}$ & $\begin{array}{l}\text { March 2019, } \\
\text { New Delhi }\end{array}$ & $\begin{array}{l}\text { Share findings } \\
\text { of the special } \\
\text { reports - SR15 } \\
\text { and SRCCL }\end{array}$ & Panel discussion & General public & Half day & NA \\
\hline 6 & $\begin{array}{l}\text { Climate Change } \\
\text { and Industry: } \\
\text { Towards a Low } \\
\text { Carbon } \\
\text { Transformation }\end{array}$ & $\begin{array}{l}\text { July 2019, } \\
\text { Ahmedabad }\end{array}$ & $\begin{array}{l}\text { Discuss the } \\
\text { methodology of } \\
\text { reporting } \mathrm{CO}_{2} \\
\text { emissions- } \\
\text { shared findings } \\
\text { of the SR } 15 \text { and } \\
\text { SRCCL }\end{array}$ & Workshop & $\begin{array}{l}\text { Industry } \\
\text { representatives }\end{array}$ & Full day & 50 \\
\hline 7 & $\begin{array}{l}\text { Conference on } \\
\text { Climate Change } \\
\text { and Land }\end{array}$ & $\begin{array}{l}\text { August } \\
2019, \\
\text { Ahmedabad }\end{array}$ & $\begin{array}{l}\text { Sharing } \\
\text { findings of the } \\
\text { Special Report - } \\
\text { SRCCL }\end{array}$ & $\begin{array}{l}\text { Conference, } 4 \\
\text { sessions }\end{array}$ & $\begin{array}{l}\text { Policymakers, } \\
\text { researchers, } \\
\text { students, civil } \\
\text { society } \\
\text { organisations }\end{array}$ & Full day & 70 \\
\hline 8 & $\begin{array}{l}\text { UNCCD COP } 14 \text { - } \\
\text { Introducing the } \\
\text { IPCC Special }\end{array}$ & $\begin{array}{l}\text { September } \\
\text { 2019, New } \\
\text { Delhi }\end{array}$ & $\begin{array}{l}\text { Share findings } \\
\text { of special report } \\
\text { - SRCCL }\end{array}$ & $\begin{array}{l}\text { Panel discussion } \\
\text { (Science Day), } 1 \\
\text { session }\end{array}$ & $\begin{array}{l}\text { Policymakers, } \\
\text { civil society } \\
\text { organisations }\end{array}$ & Half day & NA \\
\hline
\end{tabular}

Page 6/20 


\begin{tabular}{|c|c|c|c|c|c|c|c|}
\hline & $\begin{array}{l}\text { Report on Climate } \\
\text { Change }\end{array}$ & & & & & & \\
\hline 9 & $\begin{array}{l}\text { The Work and } \\
\text { Findings of the } \\
\text { Intergovernmental } \\
\text { Panel on Climate } \\
\text { Change: Three } \\
\text { special reports }\end{array}$ & $\begin{array}{l}\text { October } \\
2019, \\
\text { Hyderabad }\end{array}$ & $\begin{array}{l}\text { Sharing } \\
\text { findings of the } \\
\text { three special } \\
\text { reports (SR1.5, } \\
\text { SRCCL, SROCC) } \\
\text { and IPCC } \\
\text { process and } \\
\text { scope }\end{array}$ & $\begin{array}{l}\text { Plenary Session } \\
\text { during the Tenth } \\
\text { Biennial } \\
\text { Conference of the } \\
\text { Indian society for } \\
\text { ecological } \\
\text { economics (INSEE) }\end{array}$ & $\begin{array}{l}\text { International } \\
\text { participants: } \\
\text { Researchers, } \\
\text { subject experts, } \\
\text { early career } \\
\text { research } \\
\text { scholars, } \\
\text { students, } \\
\text { university } \\
\text { Faculty, } \\
\text { university } \\
\text { students }\end{array}$ & $\begin{array}{l}\text { Special } \\
\text { IPCC } \\
\text { Panel }\end{array}$ & 150 \\
\hline 10 & $\begin{array}{l}\text { The Work and } \\
\text { Findings of the } \\
\text { Intergovernmental } \\
\text { Panel on Climate } \\
\text { Change: Three } \\
\text { special reports }\end{array}$ & $\begin{array}{l}\text { October } \\
2019, \\
\text { Hyderabad }\end{array}$ & $\begin{array}{l}\text { Sharing } \\
\text { findings of the } \\
\text { three special } \\
\text { reports (SR1.5, } \\
\text { SRCCL, SROCC) } \\
\text { and IPCC } \\
\text { process and } \\
\text { scope }\end{array}$ & Workshop at EPTRI & $\begin{array}{l}\text { with researchers } \\
\text { from trainers } \\
\text { from } \\
\text { Environment } \\
\text { Protection and } \\
\text { Training } \\
\text { Research } \\
\text { Institute (EPTRI). }\end{array}$ & Half day & 20 \\
\hline 11 & $\begin{array}{l}\text { The Work and } \\
\text { Findings of the } \\
\text { Intergovernmental } \\
\text { Panel on Climate } \\
\text { Change: Three } \\
\text { special reports }\end{array}$ & $\begin{array}{l}\text { October } \\
2019, \\
\text { Hyderabad }\end{array}$ & $\begin{array}{l}\text { Sharing } \\
\text { findings of the } \\
\text { three special } \\
\text { reports (SR1.5, } \\
\text { SRCCL, SROCC) } \\
\text { and IPCC } \\
\text { process and } \\
\text { scope }\end{array}$ & $\begin{array}{l}\text { Workshop at } \\
\text { International Crops } \\
\text { Research Institute } \\
\text { for the Semi-Arid } \\
\text { Tropics (ICRISAT), } \\
\text { Hyderabad }\end{array}$ & $\begin{array}{l}\text { Subject experts, } \\
\text { researchers at } \\
\text { ICRISAT }\end{array}$ & Half day & 60 \\
\hline 12 & $\begin{array}{l}\text { The Work and } \\
\text { Findings of the } \\
\text { Intergovernmental } \\
\text { Panel on Climate } \\
\text { Change: Three } \\
\text { special reports }\end{array}$ & $\begin{array}{l}\text { October } \\
2019, \\
\text { Hyderabad }\end{array}$ & $\begin{array}{l}\text { Sharing } \\
\text { findings of the } \\
\text { three special } \\
\text { reports (SR1.5, } \\
\text { SRCCL, SROCC) } \\
\text { and IPCC } \\
\text { process and } \\
\text { scope }\end{array}$ & $\begin{array}{l}\text { NGO, Centre for } \\
\text { World Solidarity } \\
\text { (CWS) \& Centre for } \\
\text { People's Forestry }\end{array}$ & $\begin{array}{l}\text { Multiple NGO } \\
\text { groups, leaders, } \\
\text { action } \\
\text { researchers, field } \\
\text { workers, farmer } \\
\text { association } \\
\text { representatives }\end{array}$ & Half day & 25 \\
\hline 13 & $\begin{array}{l}\text { IPCC } \\
\text { Dissemination } \\
\text { Workshop: Key } \\
\text { Messages from } \\
\text { Three Special } \\
\text { Reports of IPCC } \\
\text { (SR 1.5, SRCCL } \\
\text { and SROCC) }\end{array}$ & $\begin{array}{l}\text { November } \\
2019, \\
\text { Kolkata }\end{array}$ & $\begin{array}{l}\text { Sharing } \\
\text { findings of the } \\
\text { three special } \\
\text { reports (SR1.5, } \\
\text { SRCCL, SROCC) } \\
\text { and IPCC } \\
\text { process and } \\
\text { scope }\end{array}$ & $\begin{array}{l}\text { Large public events } \\
\text { in well-equipped } \\
\text { state of the art } \\
\text { auditorium }\end{array}$ & $\begin{array}{l}\text { Policymakers, } \\
\text { representative of } \\
\text { state } \\
\text { government, civil } \\
\text { society, } \\
\text { university/college } \\
\text { faculty, } \\
\text { researcher, } \\
\text { formalist, } \\
\text { students, } \\
\text { school students, } \\
\text { teachers, media } \\
\text { persons }\end{array}$ & $\begin{array}{l}\text { Two full } \\
\text { days }\end{array}$ & 600 \\
\hline 14 & $\begin{array}{l}\text { Roundtable } \\
\text { Conference on } \\
\text { Cities and Climate } \\
\text { Change }\end{array}$ & $\begin{array}{l}\text { December } \\
2019, \\
\text { Ahmedabad }\end{array}$ & $\begin{array}{l}\text { Share findings } \\
\text { of special } \\
\text { reports - SR1.5 } \\
\text { and SRCCL }\end{array}$ & $\begin{array}{l}\text { Roundtable, } 4 \\
\text { sessions }\end{array}$ & $\begin{array}{l}\text { Policymakers, } \\
\text { researchers, } \\
\text { students, civil } \\
\text { society } \\
\text { organisations }\end{array}$ & Full day & 65 \\
\hline 15 & $\begin{array}{l}\text { Mitigation } \\
\text { Landscape in a } \\
\text { Carbon } \\
\text { Constrained } \\
\text { World }\end{array}$ & $\begin{array}{l}\text { December } \\
2019, \\
\text { Ahmedabad }\end{array}$ & $\begin{array}{l}\text { Share findings } \\
\text { of special } \\
\text { reports - SR } 15 \\
\text { and SRCCL and } \\
\text { how they are }\end{array}$ & Workshop, 3 & $\begin{array}{l}\text { Researchers, } \\
\text { Academics, } \\
\text { Experts, Students } \\
\text { and Social } \\
\text { Workers }\end{array}$ & Full day & 45 \\
\hline
\end{tabular}

Page $7 / 20$ 


\begin{tabular}{|c|c|c|c|c|c|c|c|}
\hline 16 & $\begin{array}{l}\text { Climate in the Age } \\
\text { of Anthropocene - } \\
\text { Kolkata Literary } \\
\text { Meet }\end{array}$ & $\begin{array}{l}\text { January } \\
2020, \\
\text { Kolkata }\end{array}$ & & $\begin{array}{l}\text { Conversation/panel } \\
\text { discussion }\end{array}$ & General public & Half day & \\
\hline 17 & $\begin{array}{l}\text { Sustainability Fair } \\
\text { - Indian Institute } \\
\text { of Technology } \\
\text { Gandhinagar }\end{array}$ & $\begin{array}{l}\text { February } \\
2020 \text {, } \\
\text { Gandhinagar }\end{array}$ & $\begin{array}{l}\text { Dissemination } \\
\text { of all } 3 \text { special } \\
\text { reports of IPCC }\end{array}$ & $\begin{array}{l}\text { Fair and } \\
\text { Conference }\end{array}$ & $\begin{array}{l}\text { Students, } \\
\text { Researchers, } \\
\text { Academics, } \\
\text { Scientist, } \\
\text { Industry, NGOs, } \\
\text { CBOs }\end{array}$ & Full day & 200 \\
\hline 18 & $\begin{array}{l}\text { World } \\
\text { Environment Day, } \\
\text { Meeting } \\
\text { organised by } \\
\text { Government of } \\
\text { Gujarat (online) - } \\
\text { Climate Change } \\
\text { Mitigation: } \\
\text { System } \\
\text { Transformations } \\
\text { for Global } \\
\text { Warming of } 1.5^{\circ} \mathrm{C}\end{array}$ & $\begin{array}{l}\text { June 2020, } \\
\text { Ahmedabad } \\
\text { (virtual } \\
\text { event) }\end{array}$ & $\begin{array}{l}\text { Share findings } \\
\text { of the SR1.5 } \\
\text { report }\end{array}$ & Webinar, 1 session & General public & Half day & 150 \\
\hline
\end{tabular}

[8] Climate change believers and Climate deniers

\section{Research Methodology \& Design}

We adopt a mixed research approach (Johnson and Onwuegbuzie 2004; Johnson et al. 2007) in analysis of the communication. The qualitative component (including interviews) in the research design help to elucidate the strengths of sensitivity to meaning and context of climate change communications. It also provides in-depth information about the understanding of the IPCC special reports. The quantitative component provides relevant information to analyse and investigate the effectiveness of climate change communications. The mixed approach of both quantitative and qualitative (including interviews) allow for increasing the strength of the research and compensating it for any its weaknesses (Punch and Oancea 2014).

There are basically three target groups for this study 1) Participants: Those who participated in the outreach events, 2) Speakers: Those who were invited as speakers during the outreach events and 3) Organisers: Those who hosted the outreach events. We carried out a survey for the participants as described below. Section 3.3 \& 3.4 discusses the inputs from IPCC authors who were also speakers and organisers of these events. The organisers conducted outreach for University and school students in three cities- Ahmedabad, Kolkata and Chennai. The feedback from these events is documented in Section 3.4.

\subsection{Survey of Participants}

Approximately 37 people were contacted based on purposive sampling (Smith and Osborn 2003) and ease of sampling due to accessibility limits and time constraints. Respondents were asked to recall their participation during the events based on their memory. Twenty-one ( $\mathrm{n}=$ 21 ) individuals agreed to participate in the study. Individuals were shared the participants questionnaire in case they attended the outreach events (See Annexure 1 in supplementary materials). The questionnaire was sent using 'Google Forms' where the individuals had to fill in the answers to the questions. They were given a week to respond to the survey, the survey was designed for a maximum of $10-15$ minutes. The analysis of the participants responses was carried out using Microsoft Office Excel. Local ethical approval had been secured, which determined there were no notable risks, dangers or hazards to the participants, who had all the rights to withdraw anytime during the process and full confidentiality and anonymity was provided. Potential limitations include generalisation of response of the questions in the survey, misunderstanding or limitation in understanding the questions, gender-based representativeness (61.9\% of the respondents were 
females), and a risk of positive bias. For the latter, since the approach was formal, route it could possibly incentivise to only report positive experiences of the outreach events.

Over half (52.4\%) of the 21 participants who responded to the survey belonged to the 21-30 years of age group, a third were between 31 and 40 years of age and the remaining were $40-55$ years old. $61.9 \%$ of the respondents were women. The occupation of the respondents is shown in Table 2.

\section{Table 2 Respondent's Occupation}

\begin{tabular}{|ll|}
\hline Respondents' Occupation & Count \\
\hline Faculty/Professor & 3 \\
\hline Doctoral Student & 3 \\
\hline Graduate Student & 3 \\
\hline Researcher & 3 \\
\hline Intern & 2 \\
\hline Private/Business & 1 \\
\hline Independent Consultant and Freelancer & 3 \\
\hline Consultancy \& NGO & 3 \\
\hline Total & $\mathbf{2 1}$ \\
\hline
\end{tabular}

\subsection{Feedback from organisers \& speakers}

The authors of this paper were also the speakers, organisers or both, for some of the outreach events. Certain aspects of information related to comprehension of climate change communications especially from perspectives of speakers and organisers is self-reported (Jupp 2006). Each of the organisers was asked to write down their feedback independently.

All the authors are directly connected to IPCC, therefore potentially making a strong case of experiencing first-hand direct reporting of understanding of science and climate change communications for IPCC special reports in India. In case of the event was hosted by two parties, depending on the availability, either of the organiser was interviewed - interviews were concluded at which point the data collection had reached the point of saturation (Strauss and Corbin 1998). Self-reporting bias (in case of speakers and organisers) was reduced by asking the participants the questions relevant to both (See Annexure 1 in supplementary materials). In total, this study includes 10 detailed responses from the combined group of speakers and organisers.

\section{Results \& Findings}

\subsection{Participants responses (overall event)}

In response to our question of why people participated in the events, $71.4 \%$ of the respondents said they were familiar with the IPCC Special reports and wanted to know more about the reports. Those aware about special reports was due to three main reasons 1) directly associated with climate change 2) were closely associated with people working in the field of climate change or 3 ) through media (e.g.newspaper, social media). $19 \%$ were not familiar with the IPCC reports but thought it might be helpful for their work and the remaining $9.5 \%$ said that the experience with the organiser during a similar event in the past was excellent.

To gain insights on how the events could have led to networking amongst different stakeholders and participants. $66.7 \%$ of the respondents found to have established a new network or contact because of the events. $19 \%$ did not find it useful and $14.3 \%$ prefer not to say (See Figure 1). Nearly $90 \%$ of the participants felt that there was enough time for the discussions during the events. And nearly $91 \%$ respondents felt that the speakers were able to connect with the widely-shared public values or points of "local interest" (See Figure 1). None of the respondents found English language to be a barrier for participation. It is important to note that all the respondents came from urban areas and were more comfortable with English language. 
To further analyse the impact of climate change communications we further asked respondents five questions, these questions were to be rated by the respondents. The rating was based on Likert scale ( $1=$ Poor, $2=$ Fair, $3=$ Good, $4=$ Very Good and $5=$ Excellent) (See Figure 2 for details).

We asked a question on the event design. The four options included i. Short sessions on individual topics ii. Panel discussions iii. Open Q\&A and iv. Mix of all. 66.7\% found Open Q\&A sessions to be most effective for communication. $61.9 \%$ of the respondents suggested that 'Short Sessions on Individual Topics' to be most effective for communications. $57.1 \%$ found panel discussions as most effective.

\subsection{Participants responses (specific)}

\subsubsection{Insights from the events - a participants' perspective}

Using thematic analysis, five themes were identified from the response of the participants, these were identified based on the response (See Figure 3). One respondent out of 21 did not wish to answer the question. $14.3 \%$ of the respondent found 'Cities and Climate Change' most insightful, the respondents emphasised more about future climate scenarios of $1.5^{\circ} \mathrm{C}$ in context of cities and the low carbon interventions that can be carried out with help of policymaking, and how stakeholder engagement is critical for better climate change communications at local levels. $14.3 \%$ of the respondent spoke about climate actions. The respondent understood the urgency of climate actions that is required for achieving the $1.5^{\circ} \mathrm{C}$ target. Also, how climate mitigation pathways are critical to policymaking and governance. One respondent out of 21, spoke about how these events have established themselves as platforms where climate discussions are expressible, healthy and open. One respondent out of 21, expressed motivation after the event of "'IPCC Dissemination Workshop: Key Messages from Three Special Reports of IPCC". The event helped the respondent connect subjects like air pollution, health, global temperatures, land use and food supply chains. Also, the respondent felt that the answers to the questions raised by the audience were dealt appropriately by the speakers. $57.1 \%$ of the respondents found their knowledge expanded because of the events. The respondent's insights were varied in nature it ranged from mitigation to SDGs to India's NDCs targets.

Among the things participants liked most about the event, included the speakers expertise and background ${ }^{[0]}$, communication skills ${ }^{[10]}$ and the quality of presentations. ${ }^{[1]}$ Some respondents commented that the events were well managed and organised, the representation of the stakeholder were diverse ${ }^{[12]}$, and the diversity of discussion during the event. ${ }^{[13]}$ Respondents also appreciated that the events helped increased understanding of participants' sectoral knowledge. ${ }^{[14]}$ Selection of speakers was also a key point. ${ }^{[15]}$

Implementing sustainable practices during the conference was appreciated. One of the participants mentioned "The use of sustainable practice from the snack, the lunch provided. Also, the jute folder provided in the event. Practice what you preach." A respondent did not like the sectoral specific discussion (example discussion about species and their ecosystems), this could be because of their personal disciplinary bias, topic preferences and interest, two respondents highlighted that the event location as least liked given that it was small and the ambience including thermal comfort.

One participant quoted "The least was the ambience. It was comfortable but not climate friendly" A respondent specifically mentioned there were too many speakers which made the events feel lengthy. A respondent mentioned how the organisers could have produced event outcomes from the presentations in form of discussion papers, research dialogues and more. ${ }^{[16]}$ Few respondents spoke about the limited interaction during the event with the audience. ${ }^{[17]}$ Speakers' presentations were not kept open source for the audience after the event and the participants registration method was least liked by a respondent. A respondent found excessive use of technical terms which they said could be discouraging.

\subsubsection{Key gaps}

Nine respondents did not report any gaps. Two of them couldn't recall the challenges due to the delay in securing feedback post the event. Lack of communications in local language was identified as a gap by a couple of participants. Some participants were disappointed over lack of event outcomes in the form of conference proceedings, discussion papers, policy brief etc. Participants from different backgrounds found it difficult to understand technical visuals. Assessment of future risk for lay person was difficult. There was limited engagement with younger audiences. Participants felt some of the topics required prior knowledge or familiarity with the reports.

Participants commented the presentations did not focus on the socioeconomic and opportunity costs imposed because of addressing issues of climate change in context of a particular region or country.

Page 10/20 


\subsubsection{On the influence of the event on the daily life}

Participants commented that insights shared during the event applied into personal work and professional work. If we analyse the relevant answers thematically, we find participants related to choices around energy consumption, waste burning, climate risks, food and transportation choice, and human ability of adaptation during extremes such as urban heat island effects during summers. Many of the suggestive solutions that participants related to included local policies, availability of Open-Source Data, enhancing social equity and incentivising green products. These are indicative of the kind of connections people can make with help of science-based communications of climate change. It is important to note that the question was open ended to an extent therefore it is possible that the answers were more like suggestions rather than a deep introspection of their own lifestyles. It could also be possible that people did not want to reveal their personal information about their daily habits and activities therefore generalised the answers.

\subsubsection{Can you recall any solutions discussed in the event? Who can play a critical role in addressing this issue and implementing solutions?}

11 people responded to this question in detail. They mentioned about governments playing a critical role at all levels and they should be engaged with citizens, CBOs \&NGOs, organisations, academia and private businesses. Also, this reflected well in the context of solutions where most of the solutions recalled by the respondents spoke about governance and policymaking with sectoral approaches for example climate financing, urban planning and design, waste segregation, renewable energy and capacity building.

\subsubsection{Which content in the event did you find difficult to understand? Why? Do you have any suggestions for improvement?}

11 out of 21 respondents either did not find any difficulty or did not wish to respond to the question. Data representation \& visualization were most spoken about as one of the most difficult to understand given that the respondents came from different disciplinary backgrounds and training. Also, including audio-visual instead of relying just on graphs and infographics could also help understand certain topics more clearly, for example event held in Kolkata, a video was prepared by IPCC communication team, the video was very well received and post workshop request for videos were received and responded by organisers. Several researchers have already captured the challenges and opportunities of graphics and data representation and visualization in IPCC reports (McMahon et al. 2015; Harold 2017; Broek 2020).

Based on personal observation all the events were exclusive of people with physical challenges and sensory impairments. Therefore, communicating the relevant information to these large groups is another challenge and difficulty. Also, IPCC reports are officially published in six official UN recognised languages (United Nations 2019) however these reports are still yet to be made inclusive for people who have visual impairments. Also, after 2007, for a report dissemination, an IPCC author with a special arrangement between the organisers and TSU, prepared booklets in two Indian regional languages.

Technical understanding of certain topics was considered a prerequisite for certain respondents. However, it could be possible that the speakers could have used too many technical terms to explain certain concepts or ideas therefore having a background knowledge to certain topics could have helped in better communications.

\subsubsection{What information from IPCC reports would you find useful?}

Sectoral level information and analysis was the most critically useful for many of the respondents. Use of systems thinking and multidisciplinary methods in IPCC reports to address sector interventions and approaches was also found to be useful by the respondents. Both of these established a precedent for the diversity of IPCC special reports coverage given that there are different stakeholders involved in policymaking process and sectoral information plays a critical role for formulating dialogues amongst stakeholders.

Accessibility to several research methodology, data and references were most useful as IPCC is considered to be the top most scientific body for assessing climate change it establishes the credibility for science backed policymaking. Future climate projections, climate pathways and climate scenarios were also talking points amongst the respondents. Though this came in context of how relevant it is to their work. Also, provision of historical climate related information and identifying research gaps were found useful by the respondents. 


\subsubsection{What key messages did you get from the event? How it has influenced your understanding of climate change?}

'Climate emergency and Climate Actions' through proper governance strategies and policymaking were the most dominating key messages amongst the responses. Followed by an 'Overview on $2^{\circ} \mathrm{C}$ and $1.5^{\circ} \mathrm{C}$ scenarios', many respondents' understandings towards both the scenarios significantly improved and further helped them understand its implication in their area of interest. Knowledge expansion was clearly visible amongst the respondents, many of the respondents spoke about how their understanding towards certain specific sectors dramatically increased after the event for example a respondent found his knowledge towards climate mitigation improved because of the

events. ${ }^{[18]}$ Some of the very specific key messages revolved around demand side solutions, land use inventory, AFOLU sector, vulnerability of population, Building sector and alternative pathways for future scenarios.

\subsubsection{Applying Sensitivity Analysis Towards Climate Action}

We asked participants how inspired they felt to take climate actions or incorporate the learnings in their professional roles. This was an important question, given that IPCC reports are said to send out alarming messages that often trigger sentimental value in the society (Lindwall 2018). With help of sentimental analysis (Tonkin 2016) we have attempted to comprehend the impact of the events for taking climate actions at the individual scale. After analysing the text using sentiment analysis, $71.4 \%$ of the respondent felt positive towards taking climate action after the events. $23.8 \%$ of the respondent response was neutral towards climate actions. One of the participants expressed negative sentiment Conclusion and future recommendations.

\subsubsection{Responses from Speakers}

The biggest challenge faced by the speakers was the unpredictability of the audience. Often speakers had no idea of the number or composition of the audience. It was not always easy to gauge how to pitch their presentation given that the uncertainty about the diversity of the audience. This made it difficult to prepare for delivery in advance and tailor messages for specific groups. For instance, at an outreach event for IPCCs Special Report on Climate Change and Land, representatives from women's organisations provided positive response and mentioned they would have liked to see more messages around gender and climate change. This 'surprise factor' made delivery challenging as speakers had to innovate in real time. As expected, speakers found it easier to connect with the academic experts and more challenging to communicate to other attendees, especially coming from a non-technical background. The most challenging issue for speakers was the inability to deliver the event in more local languages. This was also reported by one of the participants.

All speakers agreed that their contribution to outreach events was associated with a 'feel good' factor. They felt like a meaningful contribution and made them feel more purposive towards their research. However, at times, speakers felt that it became stressful when the time devoted for outreach events conflicted with their responsibilities in their day jobs.

\subsection{Responses from organisers and speakers}

Since only a few authors could contribute to outreach events, organisers had to rely on local experts to serve on panels as moderators or speakers. Often these individuals would not have sufficient knowledge of IPCC products and this resulted in the discussions deviating from the messages from the IPCC reports. In some cases, the organisers expressed an interest to offer outreach sessions in local languages. However, the unavailability of presentation materials in local languages and the inability of the experts to deliver in local language were key barriers. There were constant challenges for organisers for. e.g managing 'last minute' change in the speaker's availability and managing the timing of speakers, especially for governmental officials. For example, in one of the events held in Ahmedabad, a high-ranking city official agreed to be key note speaker but could not make it due to unforeseen circumstances. When the events are co-hosted by two organisations, this results in some compromises around the choice of speakers and the design of the event. Time management was a major issue for organisers. When some speakers spilled over, the time for Q\&A had to be compromised. Instead of this one can formulate interactive exercise enabling participants to engage actively as well as network with each other. During Round-table of Climate Change and Cities an interactive exercise was developed to increase audience participation.

It was observed that quality of food and beverages during break time sessions were positive incentives. Not all heroes wear capes, some of the most undervalued in-house support members are critical to successful implementation of the event for example services provided by

Page $12 / 20$ 
janitors, drivers, caterer etc. a simple appreciation message provides moral support and atmosphere for better future engagements, lot of it depends on personal touch and communication. In case of limited availability of human resources, the organisers had to multitask ranging from structuring events and content preparation to reaching out to audiences and sharing updates on social media. Need of professional event manager or event management team in case if the event is hosted at international and national level, given that speakers and audience logistics and other needs were to be fulfilled, if the researcher or author is hosting the event by themselves it becomes very challenging and exhausting. Interestingly, indoor climate and facilities really matter for hosting a good event. For example, one of the events hosted in Ahmedabad during summer season, when average temperature was $43^{\circ} \mathrm{C}$, non-availability of air-conditioned rooms during break time sessions made it stressful for the organisers. As observed earlier informalisation has much stronger roots for interaction during events and the environment of informalisation is available only during break time sessions. Also, if the event is hosted by a university or research institution finding students volunteers becomes very difficult without any incentive provisions. Internal room lighting \& acoustic conditions plays a huge role for smoother interaction amongst the speakers and audience. For future events local newspaper or media houses should be invited to cover the report findings.

\subsection{Feedback from outreach events with younger audiences}

Like the participants, students found these talks inspiring however an interesting difference was that at multiple events students commented on the apathy of adults towards climate action. One student quoted "Ma'am, I feel very strongly about climate change, but how do I influence the adults around me who do not share the same sentiment?" Students appreciated the videos developed by the IPCC communications team and mentioned these visually attractive and interactive sessions were quite a pleasant change from the conventional 'lecture model' they are used to in school. The authors feel an important insight for better engaging younger audience is not only one-time communication but providing multiple opportunities for engagement and using interesting reading materials and using more interactive formats.

[9] Quoted: "Most liked - the content and quality of the presentation and speaker's background"

[10] Quoted: "I loved how the sessions were so informative without being overwhelming.... the presenters discussed everything in a very simple, digestible manner; this made the information in the session easy to grasp."

[11] Quoted: "The most I liked about the event was the diversity in the speakers, which resulted in a multidisciplinary talk encompassing all the possible facets of the topic being discussed. Secondly, the speakers would provide a detailed answer yet not using a lot of jargon so that the message is conveyed effectively to the participants."

[12] Quoted: "That you reached to the local stakeholders to present and discuss the special reports was the most i liked about the events."

[13] Quoted: "Most Liked - Diverse discussion that took place”

[14] Quoted: "The conference should include hands on or small exercise on land or selected topics. I learned more on the adaptation and food security."

[15] Quoted: "Selection of speakers for the event was excellent which allowed to bring in diverse perspective on the critical issue of climate change."

[16] Quoted: "Least - We could have had better dialogues to produce something worthwhile from the presentations."

[17] Quoted: "What I liked the least was the limited interaction with the audience."

[18] Quoted: "From the events and conferences, I developed a perspective to look at the climate change from the mitigation aspects. It familiarised me with some new compelling concepts of climate change and how human behaviour, targeted scientific research, and government policies can help fight the climate crisis."

\section{Conclusion And Future Recommendations}

This study for the first-time documents impacts from climate change outreach events in India. 18 events organised between January 2019 to December 2020 were studied. Whilst these events provided a platform for reaching strategically to a wider variety of audience for

Page $13 / 20$ 
disseminating IPCC reports, these helped in identifying lessons for future IPCC events and perhaps other climate change outreach events in India.

The study has several limitations. The main limitation of the study is that it was conducted with a significant time lag after the event and therefore entirely based on the recall of the participants. This also made it challenging to secure adequate participant responses. This was further compounded by due to the ever-evolving COVID situation. The participants were mainly urban and therefore the study has not captured the challenges of communicating to people from rural areas, who are traditionally not familiar with English. The study is limited to the events the authors hosted or attended as speakers at the invitation of the IPCC or organised at their own institutions and perhaps a future study could be more comprehensive both in terms of coverage.

One of the key findings is that sector specific events attract higher stakeholder engagement and discussion compared to more general events. Locally relevant information, speakers' profile and expertise, communication abilities are critical for attracting more participants. An online survey using formal tools limits the person's ability to respond to certain information or provide very critical feedback compared to a personal interview. This could also result in a positive bias towards these events.

Despite the challenges to organising and delivering these, overall, most of the outreach events resulted in positive outcomes for speakers, organisers and most importantly for participants. Most participants were positive, however there was one respondent who expressed negative sentiment. However, the response suggests ${ }^{[19]}$ it has been written in form of a positive "sarcasm" where the respondent felt a very little incremental value towards climate action.

This survey was done months after the events were conducted and as a result several participants commented on their difficulty in recording detailed and more specific feedback. It is therefore strongly recommended that outreach events should seek feedback immediately after the event. Developing post event outcomes in the form of conference proceedings or discussion papers can become a very useful resource for future events and provide an incentive for participants' engagement at future events. Organisers can plan for these in advance, record feedback systematically and involve a few selected participants to contribute to this output post the event.

One of the limitations faced by organisers is the limited availability of sectoral experts at local level. This barrier can be resolved by implementing a hybrid format that combines elements of a physical and virtual meetings. This allows the organisers to invite IPCC authors both in person and virtually.

Researchers became "Jack of all", due to limited human resource availability at local levels and at times simultaneously playing the role of speakers as well as organisers having to handle almost everything from public engagement on social media to managing the entire events.

A good past event experience increases the chance of more engagement. Therefore, management and organisation are crucial. Developing countries face challenges of securing good venues with good infrastructure and these can play an important role in the success of an event.

Often the speakers were not fully aware of the composition of the audience they would be speaking to. The organisers can work more closely with the speakers providing them information regarding the audience in advance allowing for speakers to prepare their communication material to better align with the interests of the audience. Similarly, speakers can share their presentation material with the organisers for feedback on its relevance for the event. Nearly all participants felt that more time should be provided for interaction.

Organisers need to seek new engaging and creative formats for sessions to encourage higher participation. Coffee and tea breaks provided a useful opportunity for interaction and these should not be compromised to adjust for time spill overs during sessions. Nearly two-thirds of the participants felt they had made new contacts after the event and insights from the events influenced their professional work. For future events, it is recommended not to crowd events with too many speakers but leave it spaced out for better interaction.

Establishing methods for involving local authorities and government officials is critical for climate policy and action. A more inclusive participation would entail paying special attention to special groups. For example, improving approaches for dissemination of information for people who are physically challenged such as people who have visual and sensory impairments. Example involving sign language translator during an event so that deaf people can also understand the IPCC reports and print IPCC special reports in braille.

One of the key recommendations was to simplify technical findings and visuals for people with different backgrounds. Precise and clear data representation and visualizations play an absolute critical role for better climate change communication. Use of simple language creates an atmosphere of focus and attention. Speakers need to work on reducing jargon and simplifying their messages. This could also be done with the support of communications country specific or more local professionals if resources permit. If outreach events are supplemented with sessions in local languages, this could allow for greater representation of local groups and individuals.

Page $14 / 20$ 
Outreach for younger audiences is definitely more challenging to organise and deliver but can be very rewarding. The new and innovative approaches to making the events more interactive by designing games, debates and awarding prizes were useful in attracting their interest. In the overall, this study strongly recommends that outreach and engagement be viewed as a necessary compliment to producing the scientific reports. The recommendations in this study will be helpful for designing and delivering outreach activities for different audiences in India for AR6 and hopefully these insights may also be relevant for other scientific reports and in developing countries of similar context.

[19] Quoted: "Well, I was inspired way before such seminars to take climate actions so to me, it wasn't that inspiring, still if I want to rate, it did a small increment to 4.5 from $4 . "$

\section{Declarations}

\section{Funding}

No direct funding was received for the study. However, the authors acknowledge the support provided by the funders and in-kind support of the organisers of all the outreach events included in this study.

\section{Conflicts of interest/Competing interests}

The authors have no Conflicts of Interest

\section{Availability of data and material}

Not applicable

\section{Code availability}

Not applicable

\section{Authors' contributions}

All authors contributed to the design of the study and the writing of the manuscript. First author MP contributed to finalising the paper as well as contributing to individual sections. She helped structure the paper and design the questionnaire. Second author contributed to the structure of the paper and helped refine key insights from the study. SP and PV helped develop the survey questionnaire. SP also administered the survey to participants and collate responses. PV, SS and ND helped analysis and writing sections in the paper. SS and PV helped extensively with literature review. The last author PS helped with the overall research question and methodology

\section{Additional declarations for articles in life science joumals that report the results of studies involving humans and/or animals}

Not applicable

\section{Ethics approval}

Not applicable. The study does not violate ethical guidelines of the institutions where the authors are based

\section{Consent to participate}

The authors obtained consent from the participants surveyed for this study 


\section{Consent for publication}

The authors provide consent for publication

\section{References}

Amelung D, Fischer H, Kruse L, Sauerborn R (2016) Defogging Climate Change Communication: How Cognitive Research Can Promote Effective Climate Communication. Front Psychol 7:. https://doi.org/10.3389/fpsyg.2016.01340

Bhatta A (2013) Why don't Indian media write more on climate change? In: Thomson Reuters Found.

https://news.trust.org/item/20131021054946-Id7ms/

Billett S (2010) Dividing climate change: global warming in the Indian mass media. Clim Change 99:1-16. https://doi.org/10.1007/s10584009-9605-3

Boykoff M (2010) Indian media representations of climate change in a threatened journalistic ecosystem. Clim Change 99:17-25.

https://doi.org/10.1007/s10584-010-9807-8

Boykoff M, Luedecke G (2016) Elite News Coverage of Climate Change. In: Oxford Research Encyclopedia of Climate Science. Oxford University Press

Boykoff M, Pearman $O$ (2019) Now or Never: How Media Coverage of the IPCC Special Report on $1.5^{\circ} \mathrm{C}$ Shaped Climate-Action Deadlines. One Earth 1:285-288. https://doi.org/10.1016/j.oneear.2019.10.026

Broek K Van Den (2020) Guest post: The perils of counter-intuitive design in IPCC graphics. In: Carbon Br.

https://www.carbonbrief.org/guest-post-the-perils-of-counter-intuitive-design-in-ipcc-graphics. Accessed 9 Jan 2021

Chadha K (2017) The Indian news media industry: Structural trends and journalistic implications. Glob Media Commun 13:139-156.

https://doi.org/10.1177/1742766517704674

Chandrasekhar S, Rani G, Sahoo S (2019) Household Expenditure on Higher Education - What Do We Know and What Do Recent Data Have to Say? Econ Polit Wkly 54:9

CMS (2014) Trends in Coverage of Environment in News Channels (2009 to 2014). New Delhi

Cook J, Nuccitelli D, Green SA, et al (2013) Quantifying the consensus on anthropogenic global warming in the scientific literature. Environ Res Lett 8:024024. https://doi.org/10.1088/1748-9326/8/2/024024

Cook J, Oreskes N, Doran PT, et al (2016) Consensus on consensus: a synthesis of consensus estimates on human-caused global warming. Environ Res Lett 11:048002. https://doi.org/10.1088/1748-9326/11/4/048002

Harold J (2017) Guest Post: How IPCC graphics could be made more accessible. In: Carbon Br. https://www.carbonbrief.org/guest-posthow-ipcc-graphics-could-be-made-more-accessible

Howarth C, Painter J (2016) Exploring the science-policy interface on climate change: The role of the IPCC in informing local decisionmaking in the UK. Palgrave Commun 2:16058. https://doi.org/10.1057/palcomms.2016.58

Info Design Lab (2019) Co-designing scientific information for the IPCC special reports. In: Webpage.

https://medium.com/infodesignlabposts/co-designing-scientific-information-the-key-visualizations-of-the-ipcc-special-report-on-global-

1bbf041c72ef. Accessed 21 Jan 2021

InterAcademy Council (2010) Climate change assessments Review of the processes and procedures of the IPCC

IPCC (2007) AR4 Climate Change 2007: Synthesis Report

IPCC (2012) DECISIONS TAKEN WITH RESPECT TO THE REVIEW OF IPCC PROCESSES AND PROCEDURES COMMUNICATIONS STRATEGY. In: Intergov. Panel Clim. Chang. https://archive.ipcc.ch/meetings/session35/IAC_CommunicationStrategy.pdf. Accessed 18 Jan 2021

Page 16/20 
IPCC (2016a) Fifth Assessment Report - Synthesis report

IPCC (2018) Summary for Policymakers

IPCC (2016b) IPCC Expert Meeting on Communication. In: Webpage. https://www.ipcc.ch/event/ipcc-expert-meeting-on-communication/. Accessed 21 Jan 2021

IPCC (2021) Media Contacts. In: Webpage. https://www.ipcc.ch/news/media-contacts/. Accessed 21 Jan 2021

IPCC (2016c) IPCC Expert Meeting on Communication - Oslo, Norway • 9-10 February 2016

IPSOS (2019) Ipsos Global Trust in Professions Survey. In: Report. https://www.ipsos.com/en-in/71-urban-indians-adjudge-armed-forcesmost-trustworthy-profession-ipsos-global-trust-professions. Accessed 15 Jan 2021

Johnson RB, Onwuegbuzie AJ (2004) Mixed Methods Research: A Research Paradigm Whose Time Has Come. Educ Res 33:14-26. https://doi.org/10.3102/0013189X033007014

Johnson RB, Onwuegbuzie AJ, Turner LA (2007) Toward a Definition of Mixed Methods Research. J Mix Methods Res 1:112-133.

https://doi.org/10.1177/1558689806298224

Jupp V (ed) (2006) Self-Report Study. In: The SAGE Dictionary of Social Research Methods. SAGE Publications, Ltd, 1 Oliver's Yard, 55 City Road, London England EC1Y 1SP United Kingdom

Kapoor KK, Tamilmani K, Rana NP, et al (2018) Advances in Social Media Research: Past, Present and Future. Inf Syst Front 20:531-558. https://doi.org/10.1007/s10796-017-9810-y

Keller TR, Hase V, Thaker J, et al (2020) News Media Coverage of Climate Change in India 1997-2016: Using Automated Content Analysis to Assess Themes and Topics. Environ Commun 14:219-235. https://doi.org/10.1080/17524032.2019.1643383

Leiserowitz A, Thaker J (2012) Climate Change in the Indian Mind

Lindwall C (2018) The IPCC Climate Change Report: Why It Matters to Everyone on the Planet. In: Nat. Resour. Def. Counc. https://www.nrdc.org/stories/ipcc-climate-change-report-why-it-matters-everyone-planet. Accessed 8 Jan 2021

Livingston JE, Rummukainen M (2020) Taking science by surprise: The knowledge politics of the IPCC Special Report on 1.5 degrees. Environ Sci Policy 112:10-16. https://doi.org/10.1016/j.envsci.2020.05.020

Lynn J (2018) Communicating the IPCC: Challenges and Opportunities. In: Filho WL, Manolas E, Azul AM, et al. (eds) Handbook of Climate Change Communication: Vol. 3 - Case Studies in Climate Change Communication. Springer, Cham, pp 131-143

Maini P, Rathore L (2011) Economic impact assessment of the Agrometeorological Advisory Service of India. Curr Sci 101:16

McMahon R, Stauffacher M, Knutti R (2015) The unseen uncertainties in climate change: reviewing comprehension of an IPCC scenario graph. Clim Change 133:141-154. https://doi.org/10.1007/s10584-015-1473-4

Moser SC (2010) Communicating climate change: history, challenges, process and future directions. Wiley Interdiscip Rev Clim Chang 1:31-53. https://doi.org/10.1002/wcc.11

MRUC India (2019) Indian Readership Survey 2019 Q4. New Delhi

Murukutla N, Negi N, Puri P, et al (2017) Online media coverage of air pollution risks and current policies in India: A content analysis. WHO South-East Asia J Public Heal 6:41. https://doi.org/10.4103/2224-3151.213791

Nacu-Schmidt A, Jiménez Gómez I, Ytterstad A, et al (2019) World Newspaper Coverage of Climate Change or Global Warming, $2004-2019$. Media and Climate Change Observatory Data Sets. In: Univ. Color. Boulder. https://scholar.colorado.edu/concern/datasets/0g354g25d. Accessed 15 Jan 2021

Nivas P, Arul C, Aram A (2016) Framing of climate change issues in Indian television news channels. J Media Commun Stud 8:31-42. https://doi.org/10.5897/JMCS2015.0479

Page $17 / 20$ 
Norwegian Nobel Committee (2007) The Nobel Peace Prize 2007. In: Nor. Nobel Comm. https://www.nobelprize.org/prizes/peace/2007/summary/. Accessed 18 Jan 2021

Parveen H (2016) A Study of the Coverage of Environment and Sustainable Development in Indian English Dailies. IMS Manthan (The J Innov 11:. https://doi.org/10.18701/imsmanthan.v11i02.7765

Poberezhskaya M, Ashe T (2015) How the media spun the Paris climate agreement. In: Conversat. https://theconversation.com/how-themedia-spun-the-paris-climate-agreement-52331. Accessed 15 Jan 2021

Press Information Bureau (2005) Press Information Bureau - Information Manual Under Right to Information Act,2005

Punch K, Oancea A (2014) Introduction to Research Methods in Education. SAGE Publications Inc., New York

Rathore LS, Bhowmik SKR, Chattopadhyay N (2011) Integrated Agrometeorological Advisory Services in India. In: Challenges and Opportunities in Agrometeorology. Springer Berlin Heidelberg, Berlin, Heidelberg, pp 195-205

Roser-Renouf C, Maibach EW (2018) Strategic Communication Research to Illuminate and Promote Public Engagement with Climate Change. pp 167-218

Sampei Y, Aoyagi-Usui M (2009) Mass-media coverage, its influence on public awareness of climate-change issues, and implications for Japan's national campaign to reduce greenhouse gas emissions. Glob Environ Chang 19:203-212.

https://doi.org/10.1016/j.gloenvcha.2008.10.005

Schäfer MS, Schlichting I (2014) Media Representations of Climate Change: A Meta-Analysis of the Research Field. Environ Commun 8:142-160. https://doi.org/10.1080/17524032.2014.914050

Schmidt A, Schäfer MS (2015) Constructions of climate justice in German, Indian and US media. Clim Change 133:535-549. https://doi.org/10.1007/s10584-015-1488-x

Shreeshan V (2018) Why Indian newsrooms don't care about climate change. In: Newspaper. https://www.newslaundry.com/2018/09/04/kerala-flood-nagaland-flood-climate-change-india-media-reporting

Smith JA, Osborn M (2003) Interpretive phenomenological analysis. In: Smith JA (ed) Qualitative psychology: A practical guide to research methods. SAGE Publications Inc., London, pp 51-80

Stockholm Resilience Centre (2018) Perspectives on the Intergovernmental Panel on Climate Change 1.5C report. In: Webpage. https://www.stockholmresilience.org/research/research-news/2018-10-10-perspectives-on-the-intergovernmental-panel-on-climate-change1.5c-report.html. Accessed 21 Jan 2021

Strauss A, Corbin J (1998) Basics of qualitative research: Techniques and procedures for developing grounded theory. SAGE Publications Inc., London

Subramanian K (2019) Climate Emergency CoP 25: India must release its 2005 baseline emissions data. In: DowntoEarth. https://www.downtoearth.org.in/news/climate-change/climate-emergency-cop-25-india-must-release-its-2005-baseline-emissions-data68429. Accessed 18 Jan 2021

Svoboda M (2020) Media coverage of climate change in 2019 got bigger - and better. In: Yale Clim. Connect. https://yaleclimateconnections.org/2020/03/media-coverage-of-climate-change-in-2019-got-bigger-and-better/\#: :text=According to Media Matters\%2C in,the initial outrage over Trump's. Accessed 15 Jan 2021

Thaker J (2017) Climate Change Communication in India. In: Oxford Research Encyclopedia of Climate Science. Oxford University Press Tonkin EL (2016) Working with Text. In: Working with Text. Elsevier, pp 1-21

UNFCCC (2021) National Communication submissions from Non-Annex I Parties. In: Webpage. https://unfccc.int/non-annex-I-NCs United Nations (2019) What are the official languages of the United Nations? In: Webpage. https://ask.un.org/faq/14463. Accessed 20 Jan 2021 
Verma RK, Kumar S, llavarasan PV (2017) Government portals, social media platforms and citizen engagement in India: Some insights. Procedia Comput Sci 122:842-849. https://doi.org/10.1016/j.procs.2017.11.445

Weber EU (2010) What shapes perceptions of climate change? Wiley Interdiscip Rev Clim Chang 1:332-342. https://doi.org/10.1002/wcc.41

\section{Figures}

Do you think you were able to establish new networks/contacts because of the event?

Do you think the speaker was able to connect with the widely-shared public values or points of "local interest"?

Was English Langauge a barrier for you?

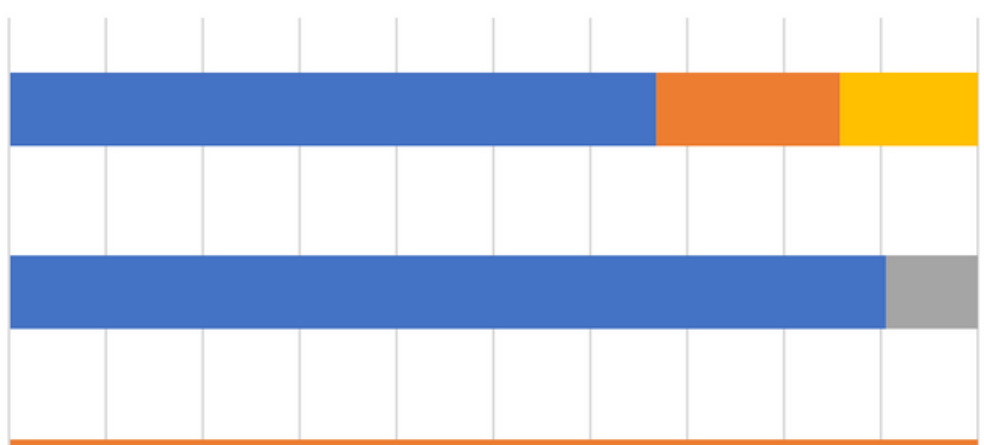

Did you think there was enough time for discussions?
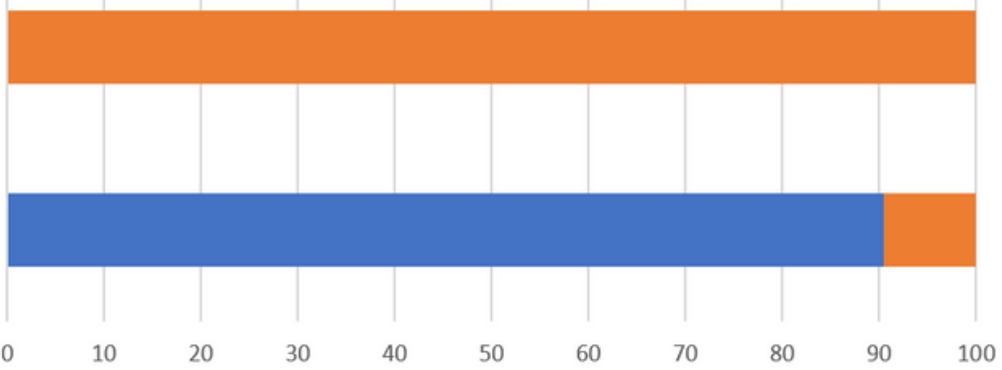

- Yes $\quad$ No Nay be $=$ Prefer not to say

\section{Figure 1}

Questions asked to respondents

How would you rate the usefulness of the information shared during the event to your job?

How would you rate the event in terms of meeting your expectations?

$\frac{n}{\frac{n}{0}}$

How effectively were speakers able to communicate key messages?

How would you rate the materials/slides presented?

How would you rate the amount of new information you learned?
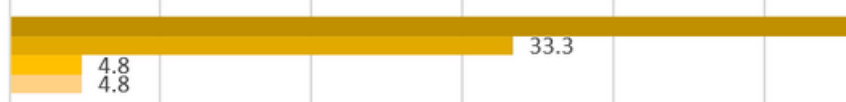

$$
\square
$$

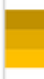

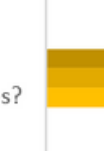

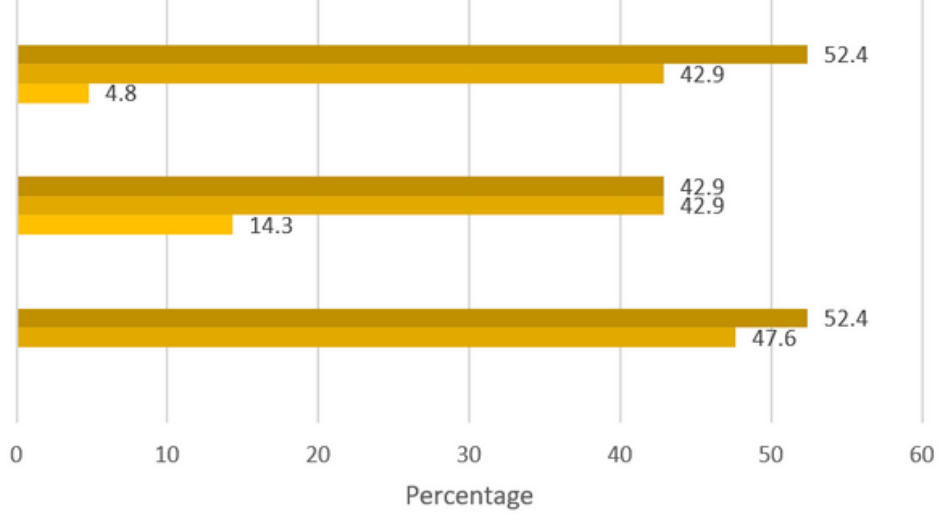

Excellent $=5$ EVery Good $=4 \quad$ a Good $=3 \quad$ Eair $=2 \quad$ Moor $=1$

\section{Figure 2}

Respondents evaluation of the outreach events 


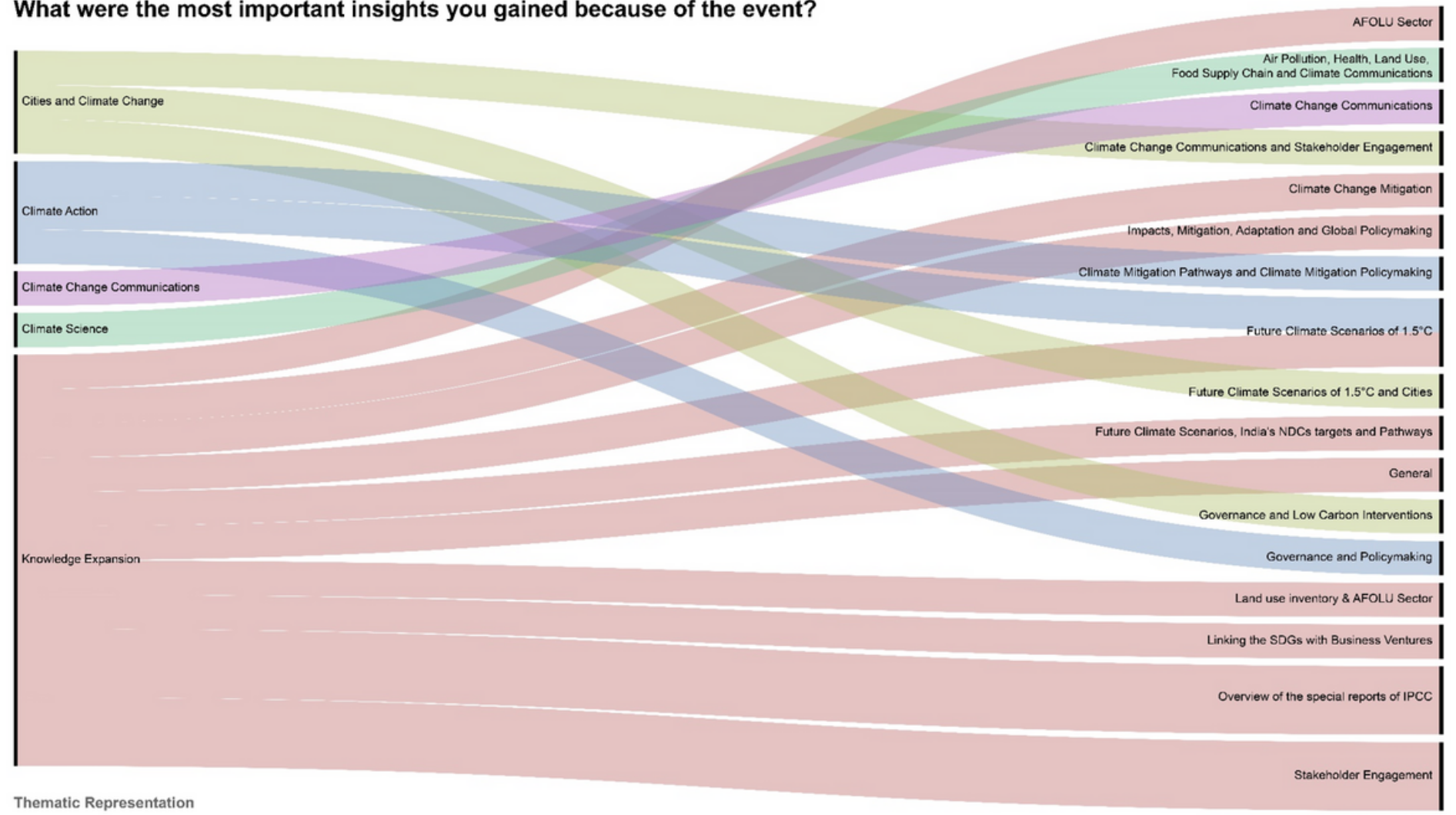

\section{Figure 3}

Thematic representation of most important insights gained by the participants due to the events

\section{Supplementary Files}

This is a list of supplementary files associated with this preprint. Click to download.

- SupplementaryMaterialPathak2021.docx 